\title{
Morphological and anatomical study of four Pyrrosia (Polypodiaeae) species from Rumbai forest, Riau Province, Indonesia
}

\author{
NERY SOFIYANTI ${ }^{1, \bullet}$, AYU KUMALA SARI ${ }^{1}$, DYAH IRIANI ${ }^{1}$, RHOZIKHINUL MUTROFIN $^{1}$, \\ IKHWAN TAUFIQ ${ }^{1}$, ERWINA JULIANTARI ${ }^{2}$, SYAFRONI PRANATA $^{3}$ \\ ${ }^{1}$ Department of Biology, Faculty of Mathematics and Natural Sciences, Universitas Riau. Jl. Pekanbaru-Bangkinang Km 12.5, Kampus Bina Widya, \\ Simpang Baru, Panam, Pekanbaru 28293, Riau, Indonesia. Tel./fax.: +62-761-63272. `email: nery.sofiyanti@lecturer.unri.ac.id \\ ${ }^{2}$ Plant Biology Graduate Program, Department of Biology, Faculty of Mathematics and Natural Sciences, Institut Pertanian Bogor. Jl. Meranti, Kampus \\ IPB Dramaga, Bogor 16680, West Java, Indonesia \\ ${ }^{3}$ Ecology Division, Generasi Biologi Indonesia (Genbinesia) Foundation. J1. Swadaya Barat No. 4, Gresik 61171, East Java, Indonesia
}

Manuscript received: 10 September 2021. Revision accepted: 20 October 2021.

\begin{abstract}
Sofiyanti N, Sari AK, Iriani D, Mutrofin R, Taufiq I, Juliantari E, Pranata S. 2021. Morphological and anatomical study of four Pyrrosia (Polypodiaeae) species from Rumbai forest, Riau Province, Indonesia. Biodiversitas 22: 4905-4914. Pyrrosia is one of genera in Polypodiaceae that is commonly distributed at Riau Forest, Indonesia. However, the detailed morphological characteristics and anatomical study of Pyrrosia in this region is scanty. This study was aimed to characterize the morphology and anatomy of four Pyrrosia species (P. angustata, P. lanceolata, P. nipoboloides and P. piloselloides) from Rumbai Forest, Riau Province. All of the specimens were collected in the field. Morphological characters were examined in detail. Anatomical preparation was conducted using the paraffin method. The specimens were then observed and photographed using a light microscope. Principal Component Analysis had been carried out using a total of 52 morphological and anatomical characters. The result showed the morphological variation a mong the species, especially on the shape of sterile lamina and sori characteristics. Anatomically, the examined species showed variations in outline shape in the transverse section of rhizomes and stipes, schelerenchymatous sheath and strand, as well as number of meristele. The PCA results showed that only three characters (shape of sterile laminae, base of sterile laminae, and upper surface color of sterile laminae) have eigenvalue over 1.00 and together these explain $100 \%$ of the total variability of the data. The anatomical data in this study is reported for the first time on Pyrrosia from Riau province.
\end{abstract}

Keywords: Fern, PCA, rhizome, stipe

Abbreviations: OE: outer epidermis; IE: inner epidermis; SS: Schelerencymatous sheath, SST: Schelerencymatous strand; TR: trichome; PA: parenchymatous part; XY: xylem; PH: phloem; EP: epidermis cell; SC: subsidiary cell; GC: guardcell

\section{INTRODUCTION}

Pyrrosia Mirbel is one of genera within Polypodiaceae (Pteridophyte), characterized by its simple leaves (Vasques et al. 2017) and the presence of stellate hair at fronds (Kotrnon et al. 2007; Zhang et al. 2013). This genus comprises ca. 59 species worldwide, and most of them occur in Southeast Asia (Vasques et al. 2017) as epiphytic and epilithic ferns (Zhang et al. 2013).

The study on morphology plays an important role in fern taxonomical studies. Basically, the morphological characters are used for the identification of new taxa (Rakotondrainibe and Hovenkamp 2012; Sofiyanti et al. 2015b; Steševic and Berg 2015; Xu et al. 2019) and classification of ferns (Lin and Viane 2013; Zhang et al. 2013). The study on morphology in ferns deals with form and structure of root (Dong et al. 2015), rhizome (Tian et al. 2014), frond (including stipe and leaf) (Vasco et al. 2013; Sofiyanti et al. 2019ab) and characteristics of sori (Churchill et al. 2011; Watkins et al. 2016). Micromorphology has also reported on the fern taxonomical studies, such as scale patterns (Nagalingum et al. 2015) and trichomes (Taha et al. 2011). The identification of ferns is mainly based on these characters. However, the polymorphism in morphological characters was previously reported on some ferns, including Pyrrosia members (Nayar and Chandra 2011).

Our preliminary study of Pyrrosia at Rumbai Forest Riau Province, Indonesia, indicated the morphological variation on this genus (Sofiyanti and Isda 2018). Therefore, morphological characterization is important to provide detailed morphological data and complete the existing description of Pyrrosia. As well as morphological characters, the importance of anatomical characters on fern had also been reported for a long period (Haq 2017; Koniyo et al. 2019; Kotrnon 2007; Talip et al. 2012). The anatomical study plays an important role in taxonomical works of fern (Dematteis et al. 2019) as well as morphological characters, several anatomical characters of fern are regarded as significant characters for identification and classification (Nopun et al. 2016). Anatomical characters of Polypodiaceae provide important findings in genera delimitation (Lagoria et al. 2018; Zhang et al. 2013), as well as species characterization within the same genus, as reported on Drynaria (Lagoria et al. 2018) and Pyrrosia from Thailand (Kortnon et al. 2007). However, 
the anatomical study of ferns (including Pyrrosia species) from Indonesia is scanty, and there are no reports on the anatomy of Pyrrosia members from Rumbai Forest, Riau Province.

The study of ferns from Riau Province had been previously reported (Sofiyanti and Isda 2018; Sofiyanti et al. 2019ab). However, only limited studies of fern anatomy from this province had been reported on other taxa such as Dicranopteris and Nephrolepis (Sofiyanti et al. 2019b), and no report was on the anatomical study of Pyrrosia from Riau Province. The study of anatomical characteristics of rhizome and stipe in ferns had been widely carried on many taxa (Nopun et al. 2016; Resmi et al. 2016; Sofiyanti et al. 2019b; Tian et al. 2014). Therefore, this study was aimed to provide the detailed morphological and anatomical characteristics of Pyrrosia from Riau Province.

\section{MATERIALS AND METHODS}

\section{Sample collection and morphological characterization}

Samples were collected in the field (Rumbai and Kampar Forest, Riau Province, Indonesia). Four Pyrrosia species examined in this study are Pyrrosia angustata (Sw.) Ching, P. lanceolata (L.) Farw., P. niphoboloides M.G. Price., P. piloselloides (L.) M.G. Price. The specimens were then collected in herbarium, and deposited at Herbarium Riauensis, Department of Biology, Faculty of Math and Natural Science. Morphological characters were described in detail.

\section{Anatomical study}

\section{Anatomy of rhizome and stipe}

The anatomical preparation had been carried out using the paraffin method followed Johansen (1940). Specimens were fixed for $24 \mathrm{~h}$ in $70 \%$ FAA, discard the solution. Dehydration was carried out in alcohol series $(70 \%, 80 \%$, $95 \%, 100 \%$ I, $100 \%$ II for $30 \mathrm{~min}$ each), followed by dealcoholization in alcohol: xylol (3:1, 1:1, 1:3), xylol I dan xylol II for $30 \mathrm{~min}$ each, and xylol: paraffin (1: 9) in oil bath for $24 \mathrm{~h}$ at $58^{\circ} \mathrm{C}$. The specimens were then soaked in paraffin at $58^{\circ} \mathrm{C}$ for $24 \mathrm{~h}$, and embedded in new paraffin and left for several days. Cut the hardened paraffin using a microtome (6 $\mu \mathrm{m}$ thick). Put the slice on object glass, dry in oven (at $45^{\circ} \mathrm{C}$.). For staining, put the object glass for 3 min in each solution: xylol I, xylol II, alcohol: xylol (1:3, 1:1, 3:1), alcohol series (absolute I, absolute II, 95\%, 80\%, $70 \%$ ), aquades, $1 \%$ safranin, $1 \%$ fast green, alcohol series (70\%, 80\%, 95\%, absolute I, absolute II), alcohol: xylol (3:1, 1:1, 1:3,), xylol I, xylol II dan xylol III. Dry the objects at room temperature, put a small piece of paraffin, cover the object using cover glass, and heat at $45^{\circ} \mathrm{C}$.

\section{Epidermal observation}

The epidermal observation was carried out from the lower and upper leaf surface to observe epidermis cells, stomata and trichomes. The stomatal preparation is based on the study of Paul et al. (2017) with modification. Transparent nail polish was smeared on the leaf surface and dried at room temperature. The transparent sticky tape was used to peel the dried nail polish. The tape was then put on the object glass. All the anatomical samples were then observed and documented using Olympus CX41 microscope.

\section{Data analysis}

The characters of morphology and anatomy were described, scored and analyzed using Principal Component Analysis, Minitab.

\section{RESULTS AND DISCUSSION}

\section{Species enumeration and morphological description}

The morphological characters were observed based on the specimens collected in the field. The detailed morphological descriptions of all Pyrrosia species examined in this study are presented here.

\section{Pyrrosia angustata (Sw.) Ching, Bull. Chin. Bot. Soc. 1} (1): 491935.

Epiphytic. Rhizome long and creeping, ca. 1.5-2.6 mm diam, dark brown at basal portion, pale brown at apical portion, scaly. Scale: non-clathrate scales, peltately attached. Fronds indistinctly dimorphic, simple. Sterile frond: petiole ca. 4-5 cm long, brown; laminae lanceolate, ca. 20-25 cm long or more by $2.5-4$, thick and leathery, widest in the middle, dark green at glabresent upper surface, greyish-green at the lower surface with stellate hairs (Thrihcome), basal cuneate, apex long acuminate. Midrib raised beneath, forming a groove at the upper surface. Fertile frond: stipe ca. 4-5 cm, brown; laminae lanceolate, ca. $30-40 \mathrm{~cm}$ long or more by $4-5 \mathrm{~cm}$ wide or more, dark green whitish light green at the lower surface with stellate hairs (Trichome), thick and leathery, wider at the middle, gradually narrower toward soriferous apical portion, margin entire, basal cuneate, apex long-acuminate, upper surface of soriferous portion knobby, soriferous portion on third toward the apex. Midrib raised beneath, forming groove at upper surface. Sori at one-third soniferous portion toward apex, almost ovale to orbicular, brown, 8 by $3 \mathrm{~mm}$ broad or more, arranged in one regular row at the leaf margin, usually sunk in shallow hollow and raised on upper surface.

Synonyms: Drynaria angustata (Sw.) Fé, Niphobolus angustatus (Sw.) Spreng, Niphopsis angustata (Sw.) J. Sm., Niphopsis angustata (Sw.) J. Sm, Polypodium angustatum Sw.

Specimens examined: PA01, PA302, PA03, PA04, Nery, Rumbai Forest, Pekanbaru, Riau, Indonesia

\section{Pyrrosia lanceolata (L.) Farw.}

Epiphytic. Rhizome long creeping, ca. 1.5-2 mm diam., dark brown, scaly. Scale: linear-lanceolate margin ciliate, non-clathrate scales, peltately attached. Frond distinctly dimorphic, simple. Sterile frond: stipe ca. 2-3.5 cm light green; laminae linear-lanceolate, ca. $15-20 \mathrm{~cm}$ long by 10 .$1.5 \mathrm{~cm}$ wide or more; light green, gradually narrowing toward both apex and base, widest below, base attetuate to conate, apex rounded, margin entire, hair stellate. Midrib 
raised beneath, forming groove at the upper surface. Fertile frond; stipe ca. 4 - $5 \mathrm{~cm}$; laminae linear-lanceolate, ca. 15$20 \mathrm{~cm}$ long or more by $1-1.5 \mathrm{~cm}$, widest below, gradually narrowing toward both apex and base, base attetuate to conate, apex rounded, light green, hair stellate. Midrib raised beneath, forming groove at the upper surface. Sori at distict pit, at two-third sofiferous portion toward apex, small, ca $1 \mathrm{~mm}$ diam., deeply sunken, round (orbicular), arranged in 5-6 layer on both sides of the mid rib.

Synonym: Acrostichum dubium Poir., Acrostichum lanceolatum L., Candollea lanceolata Mirb. ex Lam. \& Mirb., Craspedaria pertusa (Roxb. ex Hook.) Link, Cyclophorus adnascens (Sw.) Desv., Cyclophorus adnascens f. dichotoma Alderw. Cyclophorus adnascens var. minor Alderw., Cyclophorus adnascens f. pernuda Alderw., Cyclophorus cornutus Copel., Cyclophorus dimorphus Copel., Cyclophorus giesenhagenii (Christ) C. Chr., Cyclophorus glaber Desv., Cyclophorus heterophyllus Desv., Cyclophorus lanceolatus (L.) Alston, Cyclophorus nudus (Giesenh.) C. Chr., Cyclophorus pachydermus (Baker) C. Chr., Cyclophorus pustulosus Christ, Cyclophorus spissus (Bory ex Willd.) Desv., Cyclophorus spissus var. continentalis (Hieron. ex Engl.) Hieron., Cyclophorus stellatus Copel., Cyclophorus tener (Giesenh.) C. Chr., Cyclophorus varius (Kaulf.) Gaudich., Cyclophorus varius var. flabelliformis Alderw., Cyclophorus vittarioides C. Presl, Cyclosorus spissus (Bory ex Willd.) Desv., Dendroglossa lanceolata (L.) Fée, Drymoglossum martinicense Christ, Gymnopteris lanceolata (L.) T. Moore, Niphobolus adnascens var. spissum (Bory ex Willd.) Keyserl., Niphobolus adnascens (Sw.) Kaulf., Niphobolus adnascens var. varius (Kaulf.) Keyserl., Niphobolus carnosus Blume, Niphobolus caudatus Kaulf., Niphobolus elongatus Blume, Niphobolus giesenhagenii Christ, Niphobolus glaber (Desv.) Kaulf., Niphobolus heterophyllus (Desv.) Spreng., Niphobolus koenigii Blume, Niphobolus nudus Giesenh., Niphobolus pertusus (Roxb. ex Hook.) Spreng., Niphobolus spathulifer Bory, Niphobolus spissus (Bory ex Willd.) Kaulf., Niphobolus spissus var. continentalis Hieron. ex Engl., Niphobolus tener Giesenh., Niphobolus varius Kaulf., Niphobolus vittarioides T. Moore, Polypodium adnascens Hook., Polypodium carnosum (Blume) Mett., Polypodium carnosum var. elongatum (Blume) Mett., Polypodium pachydermum Baker, Polypodium pertusum Roxb. ex Hook., Polypodium spissum Bory ex Willd., Polypodium vittarioides (C. Presl) Mett., Pteropsis martinicense (Christ) Maxon, Pyrrosia caudata (Kaulf.) Ching, Pyrrosia cornuta (Copel.) Tagawa, Pyrrosia dimorpha (Copel.) Parris, Pyrrosia pachyderma (Baker) Ching, Pyrrosia stellata (Copel.) Parris, Pyrrosia varia (Kaulf.) Farw.

Specimen examined: PL01, PL302, PL03 Nery, Rumbai Forest, Pekanbaru, Riau, Indonesia.

\section{Pyrrosia niphoboloides M.G. Price.}

Epiphytic. Rhizome long creeping, ca. 1-1.8 mm diam., dark brown, scaly. Scale: non-clathrate scales, peltately attached. Frond distinctly dimorphic, simple. Sterile frond: stipe ca. $1 \mathrm{~mm}$; laminae ca. $2-3 \mathrm{~cm}$ long by $1-1.5 \mathrm{~cm}$ wide or more, green, ellipsoidal to almost ovate, wider at the middle, margin entire slightly incurved, base acuminate, apex rounded, hair stellate. Fertile frond: stipe ca. 1-3 cm; laminae ca. $10-20 \mathrm{~cm}$ long or more by $1-1.4 \mathrm{~cm}$, lanceolate-linear, base acuminate, apex acuminate with slightly lobed, green, margin entire slightly recurved, basal acuminate, apex rounded, hair stellate. Coenosori presents, superficial, sori elongated along the leaf margin an dinterupted, ca 1-2 mm wide.

Specimens examined: PN01, PN02, PA03, Nery, Rumbai Forest, Pekanbaru, Riau, Indonesia

\section{Pyrrosia piloselloides (L.) M.G. Price.}

Epiphytic. Rhizome long creeping, ca. 1-1.4 mm diam., dark brown, scaly. Scale: non-clathrate scales, peltately attached. Frond dimorphic, simple. Sterile frond: stipe ca. 1 $\mathrm{mm}$; laminae thick, $1.5-6 \mathrm{~cm}$ long by $1-1.5 \mathrm{~cm}$ wide or more, green, circular, elliptical or obovate, wider at the middle, margin entire, apex rounded, hair stellate. Fertile frond: stipe ca. 1-3 cm; laminae ca. 10-20 cm long or more by $1-1.4 \mathrm{~cm}$, lanceolate-linear, base acuminate, apex round, green, margin entire, hair stellate. Coenosori presents, superficial, sori elongated along the leaf margin, except at the base, ca 1-2 mm wide.

Synonyms: Drymoglossum piloselloides (L.) C. Presl, Drymoglossum rotundifolium C. Presl, Drymoglossum piloselloides var. platycerioides Z. Teruya, Lemmaphyllum piloselloides (L.) Luerss., Notholaena piloselloides (L.) Kaulf. ex Kaulf., Oetosis piloselloides (L.) Kuntze, Pteris piloselloides L., Pteropsis piloselloides (L.) Desv., Taenitis piloselloides (L.) R. Br.

Specimens examined: PP01, PP02, PP03, PP04, PP05, Nery, Rumbai Forest, Pekanbaru, Riau, Indonesia

During our exploration at Rumbai Forest, Riau Province, we observed that all of the Pyrrosia members are epiphityc and growing on tree trunks, such as Mango (Mangifera indica), Rambutan (Nephellium lapaceum) and Mahogany (Swietenia mahogany). The field observation of Pyrrosia showed different growth habits. The growth of $P$. angustata usually forms clusters. This habit was also reported from the same species collected from the different forests in Riau Province (Sofiyanti et al. 2015b). The laminae of $P$. lanceolata, $P$. niphoboloides and $P$. piloselloides are more sparsely located. P. angustata is commonly found at the base of the tree trunk, while three other species are found on some parts of the tree and densely attached to twigs, branches, and trunks of the host tree.

The rhizomes of all four Pyrrosia species examined in this study are creeping. In this study, $P$. angustata has the widest diameter of rhizome (up to $2.6 \mathrm{~mm}$ ), followed by $P$. lanceolata (up to $2 \mathrm{~cm}$ ). While $P$. niphoboloides and $P$. piloselloides have the smallest diameter of rhizome (ca. 1 $\mathrm{mm}$ ). Most Pyrrosia species have rhizome diameters less than $5 \mathrm{~mm}$. However, the widest diameter was reported on $P$. boothii (Hooker) Ching, which reach up to $8 \mathrm{~mm}$ (Zhang et al. 2013).

The presence of rhizome scale becomes the characteristic of Polypodiaceae genera, including Pyrrosia (Zhang et al. 2013). Scale characteristic is an important character in species delimitation of this genus, as reported 
by Kortnon et al. (2007). Hovenkamp (1986) had reported type of scale rhizome of Pyrrosia, i.e. baxified, peltate and pseudopeltate. According to Kato and Tsutsumi (2008), scales with basified type have no stalk, and are attached by broad bases, while peltate and pseudopeltate scales comprise stalk and shield. The difference of those types is in the position of the stalk, inserted near the center of the shield in peltate scale (Ranil et al. 2006), or strictly at the base of the shield in pseudopeltate scales. The basified and pseudopeltate scale were reported on Pyrrosia princeps (Mett.) Morton and Pyrrosia schimperiana (Kuhn) Alston., respectively (Hovenkamp 1986). In this study, all of examined Pyrrosia species have a peltate scale.

Watkins et al. (2016) reported three categories of morphological divergence in ferns, i.e. monomorphic, hemidimorphic, and holodimorphic or dimorphic. In monomorphic ferns, there is no difference in the shape of fertile and sterile fronds, because there are produced with a similar degree of laminar area (Hovenkamp 1986; Watkins et al. 2016). Hemidimorphic ferns have the same frond that is separated into sterile and fertile portions and usually fertile fronds are significantly reduced laminar area (Watkins et al. 2016), as reported on Aglaomorpha meyeniana (Vasco et al. 2013). The term subdimorphic is reported in fern by Zhang et al. (2013). Holodimorphic or dimorphic ferns show the extreme reduction of laminar area of fertile fronds (Watkins et al. 2016). The term holodimorphic in ferns had been reported earlier by Wagner and Wagner (1977), to indicate a total loss of vegetative function on sporophyll. In Pyrrosia members, the categories of morphological divergence that had been reported were monomorphic e.g. $P$. sheareri (Baker) Ching (Hovenkamp 1986) and P. stigmosa (Swartz) Ching (Zhang et al. 2013); subdimorphic e.g. $P$. nuda (Giesenhagen) Chin and dimorphic (P. piloselloides) (Zhang et al. 2013).

In this study, we observed dimorphic frond type at all of the examined species. However, the fertile and sterile fronds in $P$. angustata and $P$. lanceolata sometimes are not clearly distinct, due to its similar shape and size. The variation of frond type was reported by Hovenkamp (1986) on $P$. lanceolata, with moderately to strongly dimorphic frond and distinctly or indistinctly stipitate. The shape of sterile fronds among the species observed are lanceolate $(P$. angustata), linear to lanceolate $(P$. lanceolata), ovale $(P$. niphoboloides) and almost circular to ovale ( $P$. piloselloides). $P$. angustata has the biggest sterile laminae (up to $25 \mathrm{~cm}$ long) than other Pyrrosia in this study. The smallest size of sterile laminae was recorded from $P$. piloselloides (ca. $8 \mathrm{~mm}$ long).

The identification of Pyrrosia species has to be carefully carried out due to the morphological variation, especially on the shape of sterile laminae, as recorded on $P$. heterophylla. In this study, we observed that sterile laminae of $P$. niphoboloides and $P$. piloselloides are more variable in shape, than $P$. angustata and $P$. lanceolata. $P$. niphoboloides showed ellipsoidal to ovate shape and $P$. piloselloides showed the circular, elliptical or obovate shape of sterile laminae. However, the most common shapes are circular or elliptical. The obovate shape of sterile laminae was also reported by Tsutsumi et al. (2018) on P. piloselloides collected from Bogor Botanic Garden, West Java Province.

The shape and size of fertile laminea vary among the species observed. Usually, the fertile laminae of Pyrrosia is longer and narrower than sterile laminae. The strongly dimorphic fronds were found in both $P$. niphoboloides and $P$. piloselloides. These two species showed the different shapes of fertile laminae, ie. Lanceolate-linear. The length of this laminae is almost three to four times longer than sterile laminae. Therefore, both sterile and fertile laminae are easily recognized during the observation. The laminae of $P$. niphoboloides and $P$. piloselloides are distinguished by their margin and tip of laminae. $P$. niphoboloides showed incurved margin and slightly lobed tip of laminae. On the other hand, $P$. piloselloides showed an entire margin with a rounded laminea tip.

The observation of fertile lamina of $P$. angustata and $P$. lanceolata indicated a similar shape with sterile laminae, i.e. lanceolate and linear-lanceolate, respectively. However, in fertile laminae the soniferous portion is gradually narrower and longer. The fertile laminae of both species are widest below. However, the lamineae color of $P$. angustata is different from $\mathrm{P}$, lanceolate. $P$. angustata has dark green color on the upper surface of laminae and greyish green at the lower surface. On the other hand, P. lanceolata showed a light green color of laminenae. These species were also distinguished by the characteristic of soniferous portions. $P$. angustata has one-third sobiferous portions toward the apex, and $P$. lanceolata has two third soniferous portion toward the apex. The dorsal surfaces of $P$. angustata are knobby at soniferous portion, indicating the deeply sunken sori at the ventral surface.

Sori is one of the important characteristics of fern identification. Zhang et al. (2013) recorded two types of sori in Pyrrosia, i.e. longitudinally elongated (coenosori) and orbicular or slightly elongated. In this study, coenosori is found in $P$. niphololoides and $P$. piloselloides, while orbicular in P. lanceolata and $P$. angustata. However, sori of $P$. angustata observed in this study is almost ovale than in P. lanceolata. In sori position, both $P$. niphoboloides and $P$. piloselloides also show a similar pattern, with superficial and marginal sori. In contrast, $P$. angustata and $P$. lanceolata have sunken sori, and cover the lower surface of soniferous portion. The sori size in $P$. angustata are larger than in P. lanceolata. $P$. angustata also have a knobby area at the upper surface of soniferous portion. Hovenkamp (1986) had proposed a total of 10 Pyrrosia groups based on the characteristic of morphology. In this study, we identified 3 out of 10 groups, i.e. The P. angustata-group (characterized by the contraction of the sori into a single row), The $P$. lanceolata-group (characterized by the deeply sunken sori) and $P$. piloselloides-group (characterized by the presence of coenosori). The last group comprises two species, i.e. $P$. piloselloides and $P$. niphoboloides.

\section{Anatomical study}

In this study, the anatomy of the rhizome and stipes was observed. Figure 1 and 2 present the anatomy of rhizome and stipe, respectively. The range of quantitative data was 
measured based on 5 points of view of anatomical specimens.

\section{Pyrrosia angustata}

Rhizome almost ovale in outline, ca $2.75 \mathrm{~mm}$ in diam, scaly (Figure 1A). Scale T-shaped in cross-section, multiceluler, stalk ca. $60-70 \mu \mathrm{m}$ in height, tip in transverse section slightly concave (Figure 1E). Epidermis: polygonal, 2-3 layered, outer part formed of compactly packed cells ca. 40-55 $\mu \mathrm{m}$ long, inner layer with various size (Figure 1I). Ground tissue (cortex) consisted of many layers, outer with 6-8 sclerenchymatous layers, cell size ca. 20-45 $\mu \mathrm{m}$ long; inner parenchymatous, cell size ca. 25-45 $\mu \mathrm{m}$ long. Stelar dictiostele. Meristele 9 bundles, almost rounded, size almost similar, each meristele covered by endodermis. Sclerencymatous strands located around meristele, vascular. Vascular bundle concentric-amphicribral, xylem compact in the middle, xylem cells is bigger than phloem. Petiolus: outline almost globose in transverse section (Figure 2A). Epidermis polygonal with flat anticlial cell walls (Figure 2E). Ground tissue (cortex) outer with 2-3 sclerenchymatous sheaths (Figure 2I) inner parenchymatous, cell size ca. 35-55 $\mu \mathrm{m}$ long (Figure 2M). Stelar type dictiostele, with 5 meristele. Vascular bundle concentric-amphicribral, ovale-shaped, xylem cells bigger than phloem. (Figure 2M). Stomata: hypostomatic, pericytic; guard cells reniform ca $37.90 \pm 4.54$ by $33.50 \pm$ 2.40; subsidiary cells irregular, two cells. Trichome: stellate hair.

Sample code: PA-Rh1, PA-Rh2, PA-RH3 (rhizome): PA-St, PA-St2 (stipe); PA-Ep1 (stomata and trichome).

\section{Pyrrosia lanceolata}

Rhizom almost circular in outline, ca. $1.5 \mathrm{~mm}$ in diam., scaly (Figure 1B). Scale T-shaped in cross-section, multicelular, stalk ca. $40-45 \mu \mathrm{m}$ in height, tip in transverse section slightly concave. Epidermis: polygonal, 2-4 layered, outer part formed of compactly packed cells ca. 30-40 $\mu \mathrm{m}$ long, inner layer consisted of various cell size (Figure J). Ground tissue (cortex) consisted of many layers, outer with 3-5 sclerenchymatous layers, cell size ca. 15-35 $\mu \mathrm{m}$ long; inner parenchymatous, cell size ca. 20-40 $\mu \mathrm{m}$ long (Figure 1N). Sclerenchymatous strands located at the inner parenchyma part, centrally arranged. Stelar dictiostele. Meristele 4 bundles, almost ovale-shaped, one meristele has the biggest size (ca. $35 \mu \mathrm{m}$ long), each meristele covered by endodermis. Vascular bundle concentric-amphicribral, xylem compact in the middle, xylem cells are bigger than phloem. Stipe: outline almost heart-shaped in transverse section (Figure 2B). Epidermis irregular-shaped with sinous anticlial cell walls. Ground tissue (cortex) with 3-4 sclerenchymatous sheaths (Figure 2F), inner parenchymatous (Figure 2J). Stelar type dictiostele, with 5 meristele. Vascular bundle concentricamphicribral, ovale-shaped, xylem cells bigger than phloem. (Figure 2N). Stomata reniform, hipostomatic, pericytic; guard cell $31.44 \pm 1.54$ by $26.23 \pm 3.11$; subsidiary cells polygonal, $2-4$ cells. Trichome: stellate hair.
Sample code: PL-Rh1, PL-Rh2, PL-RH3 (rhizome): PL-St1, PL-St2, PL-St3 (stipe); PL-Ep1 (stomata and trichome).

\section{Pyrrosia niphoboloides}

Rhizom almost circular in outline, with flatter side abaxially, ca. $1.4 \mathrm{~mm}$ in diam., scaly (Figure 1C). Scale Tshaped in cross-section, multicellular, stalk ca. $35-40 \mu \mathrm{m}$ in height, tip in transverse section convex (Figure 1G). Epidermis: polygonal, 2-3 layered, outer part formed of compactly packed cells ca. 20-30 $\mu \mathrm{m}$ long, inner layer consisted of various cell size (Figure $1 \mathrm{~K}$ ). Ground tissue (cortex) consisted of many layers, outer with 2-3 sclerenchymatous layers, cell size ca. 25-40 $\mu \mathrm{m}$ long; inner parenchymatous, cell size ca. 10-40 $\mu \mathrm{m}$ long. Stelar dictiostele. Meristele 4 bundles, almost ovale-shaped, one meristele has the biggest size (ca. $30 \mu \mathrm{m}$ long), each meristele covered by endodermis. Vascular bundle concentric-amphicribral, xylem compact in the middle, almost ovale-shaped, broader at the middle, xylem cells bigger than phloem. Stipe: outline almost wing-shaped in transverse section (Figure 2C). Epidermis tubular-shaped with flat anticlial cell walls. Ground tissue (cortex) outer with 1- 3 sclerenchymatous sheaths, inner parenchymatous. Stelar type dictiostele, with 5 meristele. Vascular bundle concentric-amphicribral, xylem cells bigger than phloem. Stomata hipostomatic, pericytic guard cell reniform, 34.76 \pm 3.02 by $32.62 \pm 3.03$; subsidiary cells polygonal, three cells. Trichome: stellate hair.

Sample code: PN-Rh1, PN-Rh2, PN-RH3 (rhizome): PN-St1, PN-St2, PN-St3 (stipe); PN-Ep1 (stomata and trichome).

\section{Pyrrosia piloselloides}

Rhizom is almost circular in outline, with flatter side abaxially, ca. $9 \mathrm{~mm}$ in diam., scaly (Figure 1D). Scale Tshaped in cross-section, multicelular, stalk ca. $20-30 \mu \mathrm{m}$ in height, tip in transverse section convex (Figure 1G). Epidermis: polygonal, 2-3 layered, outer part formed of compactly packed cells ca. 20-25 $\mu \mathrm{m}$ long, inner layer consisted of various cell size. Ground tissue (cortex) consisted of many layers, outer with 2-3 sclerenchymatous layers, cell size ca. 10-40 $\mu \mathrm{m}$ long; inner parenchymatous, cell size ca. 10-40 $\mu \mathrm{m}$ long (Figure $1 \mathrm{~K}$ ). Stelar dictiostele. Meristele 4 bundles, almost ovale-shaped, 1 meristele has the biggest size (ca. $30 \mu \mathrm{m}$ long), each meristele covered by endodermis. Vascular bundle concentric amphicribral, xylem compact in the middle, almost ovale-shaped, broader at the middle (Figure 1O). Stipe: outline wing-shaped in transverse section (Figure 2D). Epidermis tubular-shaped with flat anticlial cell walls. Ground tissue (cortex) with 1 2 sheaths inner parenchymatous (Figure 2K). Stelar type dictiostele, with 5 meristele. Vascular bundle concentricamphicribral, (Figure 2P). Stomata hipostomatic, adaxial surface without stomata (Figure 3A), pericytic; guard cell reniform, $33.22 \pm 1.81$ by $29.26 \pm 2.89$; subsidiary cells polygonal, three cells (Figure 3B). Trichome: stellate hair.

Sample code: PP-Rh1, PP-Rh2, PP-RH3 (rhizome): PPSt1, PP-St2, PP-St3 (stipe); PP-Ep1 (stomata and trichome). 


\section{Rhizome}

The study of anatomy in fern had been previously reported (Haq 2017; Kotrnon 2007; Resmi et al. 2016; Talip et al. 2012). In this study we examined the anatomy of the rhizome and stipe. The outline of the rhizome in the transverse section show two shapes, i.e. almost ovale $(P$. angustata), almost circular ( $P$. lanceolate, $P$. niphoboloides and $P$. piloselloides). The scale of these four species is similar (non-clathrate and peltate scale). Non-clathrate scales do not have a latticelike appearance or structure.
This structure is commonly found in Asplenium (Aspleniaceae). The peltate scales have a cylindrical stalk that is attached near of below the center of the shield (Tsutsumi and Kato 2009). The transverse section of scales presented in figure $1(\mathrm{D}-\mathrm{G})$ shows a T-shaped scale and the tip of scale are concave ( $P$. angustata and $P$. lanceolata) and convex tip ( $P$. niphoboloides and P. piloselloides). The scale stalk height varies within the species, ca. 20-30 ( $P$. piloselloides), 35-40 $\mu \mathrm{m}$ ( $P$. niphoboloides), 40-45 ( $P$. lanceolata) and 50-70 $\mu \mathrm{m}$ (P. angustata).
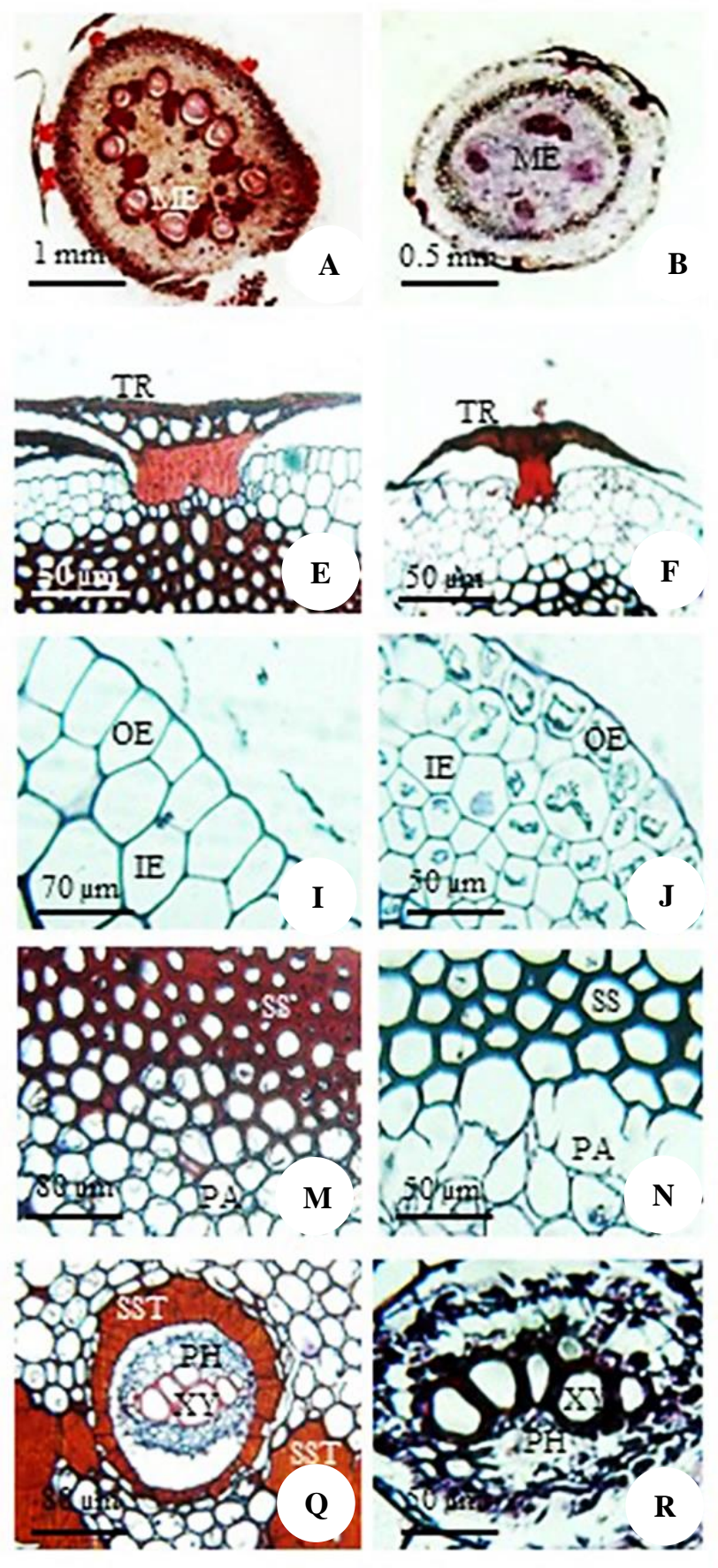
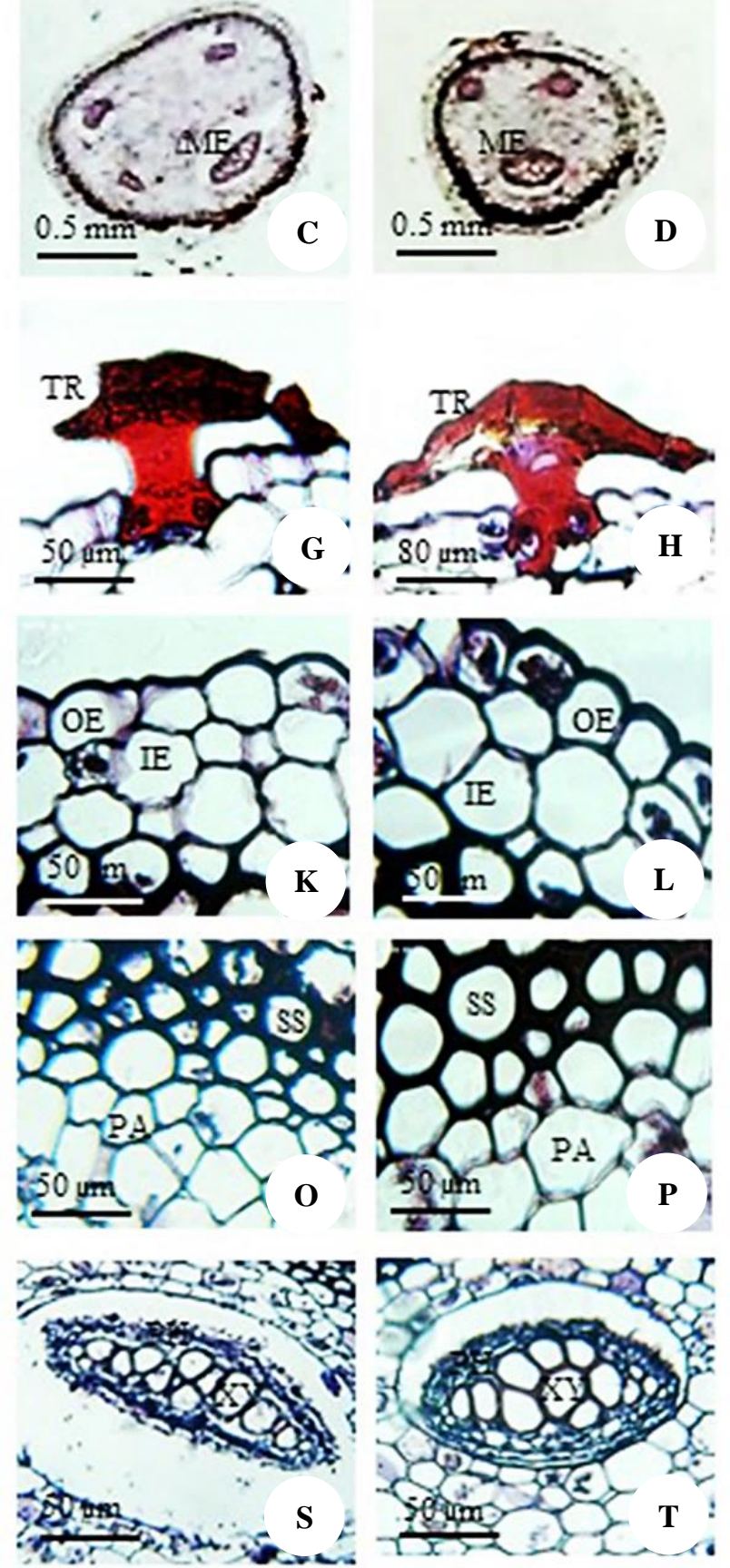

Figure 1. Rhizome anatomy of four Pyrrosia. (P. angustata (A, E, H, L); P. lanceolata (B, F, J, N, R); P. niphoboloides (C, G, K, O, S) and $P$. piloselloides $(\mathrm{D}, \mathrm{H}, \mathrm{L}, \mathrm{P}, \mathrm{T})$ ). (A-D outline of rhizome in transverse section; E-G. transverse section of rhizome showing trichome; H-K. Cortex L-O. meristele; OE: outer epidermis; IE: inner epidermis; SS: Schelerencymatous sheath; SST: Schelerencymatous strand; TR: trichome; PA: parenchymatous part; XY: xylem; PH: phloem) 

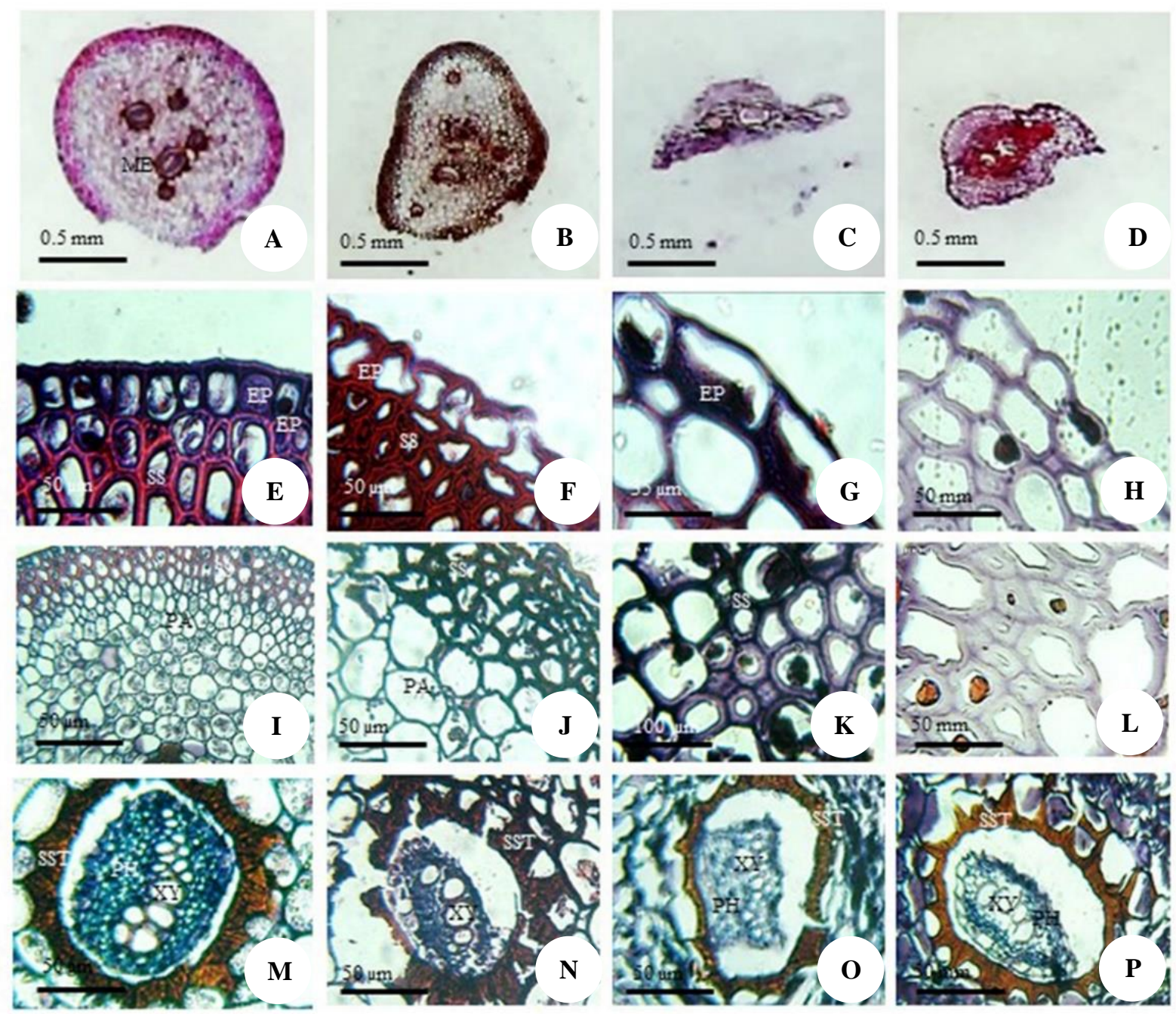

Figure 2. Stipe anatomy of four Pyrrosia. (P. angustata (A, E, I, M); P. lanceolata (B, F, J, N); P. niphoboloides (C, G, K, O) and P. piloselloides (D, H, L, P)). (A-D outline of stipes in transverse section; E-H epidermis and sclerenchymatous sheath; I-J parenchymatous part; M-P. meristele). EP: epidermis; SS: Schelerencymatous sheath; SST: Schelerencymatous strand; PA: parenchymatous part; XY: xylem; PH: phloem)

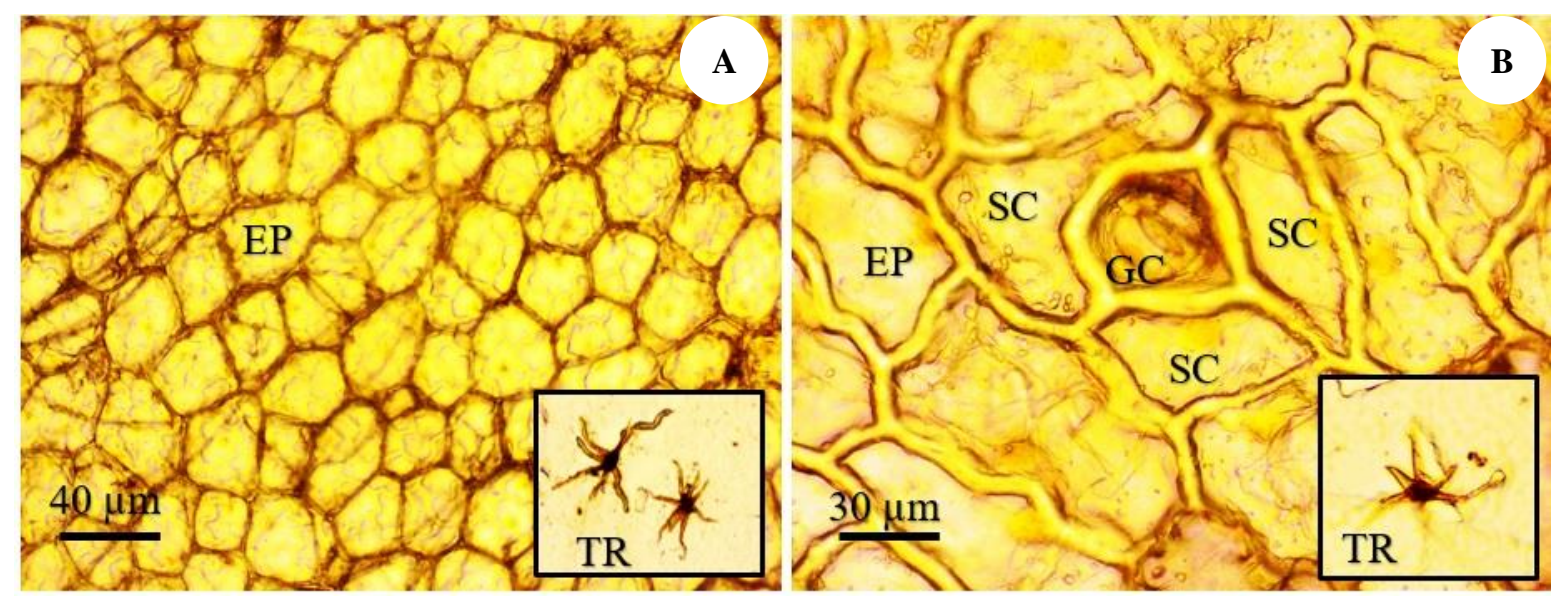

Figure 3. Epidermis of Pyrrosia piloselloides. A. Adaxial without stomata, B. Abaxial with perycytic stoma (insert: trichome with stellate hair) (EP: epidermis cell; SC: subsidiary cell; GC: guardcell; TR: trichome) 
Epidermis cells of rhizome in all of the examined species are polygonal, usually 2-4 layers, the outer cells are thickly walled, beneath the epidermis cells. We observed that ground tissue comprises of schlerencymatous (outer) and followed by parenchymatous layers with thin wall cells at the inner side. Usually, the schlerencymatous cells have smaller sizes and thicker cells than parenchymatous cells. $P$. angustata has the highest number of schlerenchymatous sheath (6-8 layers), followed by $P$. lanceolata (3-5 layers), while $P$. nipholobolides and $P$. piloselloides showed similar number, 2-3 layers. The number of schlerenchymatous sheaths in this study is almost similar to the result of Kotrnon et al. (2007) that investigated Pyrrosia from Thailand, including $P$. angustata, $P$. lanceolata and $P$. piloselloides. However, the schlerenchymatous strands are only found in $P$. angustata and P. lanceolata. Hovenkamp (1986) and Kotrnon et al. (2007) also reported the presence of schlerenchymatous strands in this species. Furthermore, Kotrnon et al. (2007) recorded that in the rhizome of Pyrrosia, a total of four arrangements of sclerenchymatous strand had been observed, i.e. scattered irregularly, restricted to the peripheral zone, located centrally in the inner parenchyma and absent. In this study, the arrangement of schlerenchymatous strand are restricted to the peripheral zone encircles the vascular bundle $(P$. angustata), located centrally in the inner parenchyma $(P$. lanceolata) and absent $(P$. niphoboloides and $P$. piloselloides). Hovenkamp (1986) reported that the arrangement of sclerenchymatous strands in Pyrrosia had important taxonomic value for this genus.

The stellar type in the rhizome of all species in this study is dyctiostele. This stele is broken up into a network of meristele (vascular strand) that is separated by parenchymatous cells, usually the meristele varies in shape and size and surrounds by endodermis (Moran and Labiak 2015). Dyctiostele stellar type was also reported on other genus in Polypodiaceae, such as Drynaria, Microsorum, Selliquea (Nopun et al. 2016), Pleopeltis (Lagoria et al. 2018.) According to Nopun et al. (2016), this stelar type is also commonly found in other fern taxa. The number of meristele in this study varies within the species, i.e. $9(P$. angustata), 4 ( $P$. lanceolata and $P$. niphoboloides) and 3 $(P$. pilloseloides). Usually, one meritele has a bigger size

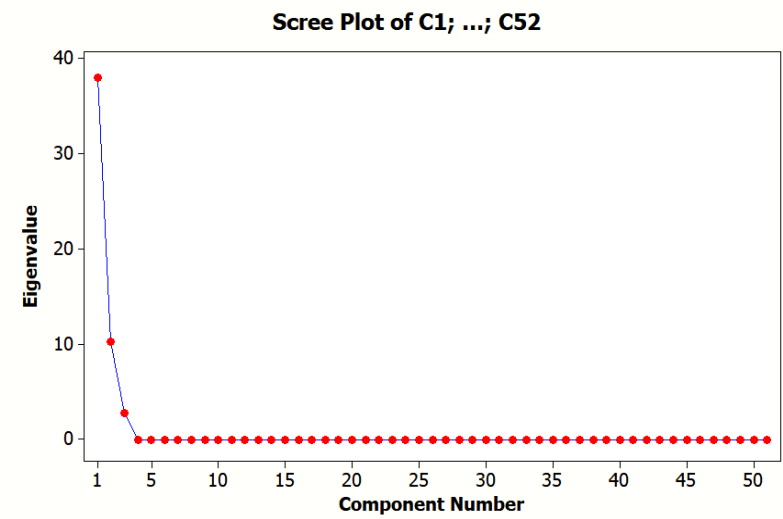

A

Figure 4. Result of PCA. A. Scree plot, B. Biplot

Table 1. Principal component value of four examined Pyrrosia based on 10 selected characters than the other meristeles. The type of vascular bundle is concentric-amphicribral, in which the phloem encircles the xylem entirely. This bundle is closed due to the absence of cambium.

\section{Stipe}

The outlines of the stipe in the transverse section are globose $(P$. angustata), almost heart-shaped ( $P$. lanceolata) and wing-shaped ( $P$. niphobolides and $P$. piloselloides). Three other outlines of Pyrrosia stipe in the transverse section in Pyrrosia had been recorded by Kotrnon et al. (2007), i.e. round ( $P$. mollis), spindle-shaped ( $P$. tonkinensis) and elliptical-shaped ( $P$. piloselloides). The wing-shaped stipe of $P$. piloselloides in this study is caused by the narrow-elongated base of laminae toward the stipe base.

The epidermal cells arrange in 1 layer, with various cell shapes, i.e. polygonal ( $P$. angustata), irregular $(P$. lanceolata) and tubular $(P$. niphobolides and $P$. piloselloides). The anticlinal cell walls are flat, except in $P$. lanceolata (sinous). Below the epidermis, the schlerenchymatous sheath is arranged in 1-4 layers. The stellar type is dyctiostele, with a similar number of meristele in all of the species observed ( 5 meristele), with a concentric-amphicribral vascular bundle.

\section{Stomata and trichome}

The stomatal complex of all the examined Pyrrosia species are hypostomatic, in which the stomata are absent in the adaxial surface (Figure 3A) and only found in the lower surface (abaxial) of laminae (Crang et al. 2019) as seen in Figure 3B. In this study, the stomatal pattern of all four examined Pyrrosia is pericytic, in which the guard cells have been detached from the subsidiary cells. This pattern had been reported earlier on Pyrrosia members Hovenkamp (1986), Cheng et al. (2014). Pyrrosia members is also characterized by the presence of trichomes with stellate hairs on both adaxil and abaxial surface of laminae (Figure $3 \mathrm{~A}$ and B, insert). This structure is densely found abaxially. The characteristic of trichome is an important value for the identification of Pyrrosia species (Hovenkamp 1986; Cheng et al. 2014; Sofiyanti and Isda 2018).

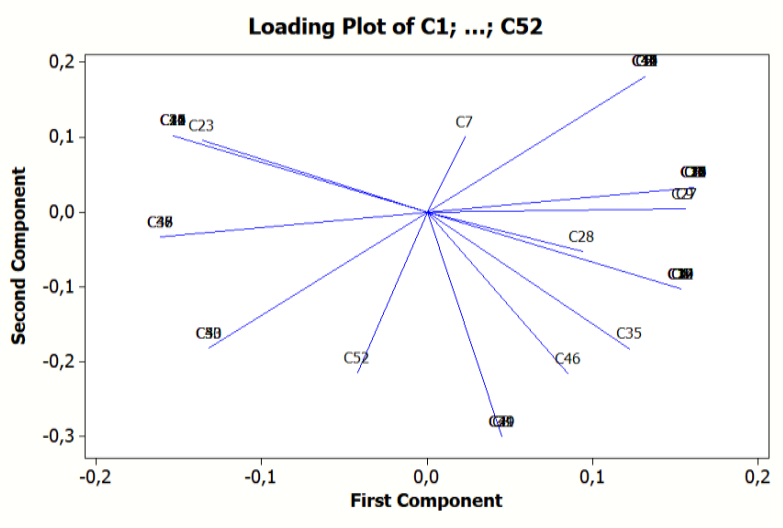

B 


\begin{tabular}{llll}
\hline Characters & PC1 & PC2 & PC3 \\
\hline $\begin{array}{l}\text { Shape of sterile laminae } \\
\text { Base of sterile laminae }\end{array}$ & 0,023 & 0,101 & $-0,566$ \\
$\begin{array}{l}\text { Upper surface color of sterile } \\
\text { laminae }\end{array}$ & 0,045 & $-0,300$ & $-0,008$ \\
$\begin{array}{l}\text { Lower surface color of sterile } \\
\text { laminae }\end{array}$ & 0,161 & 0,033 & 0,026 \\
Length of fertile frond petiole & 0,033 & 0,026 \\
Width of fertile laminae & 0,161 & 0,033 & 0,026 \\
Shape of fertile laminae & 0,045 & $-0,300$ & $-0,0008$ \\
Shape of sori & 0,161 & 0,033 & 0,026 \\
$\begin{array}{l}\text { Number of epidermis layer of } \\
\text { rhizome }\end{array}$ & 0,045 & $-0,300$ & $-0,008$ \\
Anticlinal walls & & & \\
Eigenvalue & 0,045 & $-0,300$ & $-0,008$ \\
Proportion $(\%)$ & 38,000 & 10,264 & 2,735 \\
Cumulative (\%) & 74,50 & 20,10 & 5,40 \\
& 74,50 & 94.60 & 100 \\
\hline
\end{tabular}

\section{Principal Component Analysis (PCA)}

Principal component analysis (PCA) is a tool to examine the relationships in continuous multivariate data, that was first introduced by Pearson (Mishra et al. 2017). The principle component captures the most variation in a data set (Jolliffe and Cadima 2016). This analysis develops a small set of uncorrelated components based on the scores on the variables (Santos et al. 2019). In this study we combine morphological and anatomical characters with being analyzed using PCA, with a total of 52 characters. The result shows that only the first three characters have eigenvalue over 1.00 (Table 1) and together these explain $100 \%$ of the total variability of the data. Eigenvalue represents the amount of variation retained by each principal component. The conclusion based on the first three components is supported by the scree plot (Figure 4A). The scree plot is a line plot of the eigenvalue of the principal component (Santos et al. 2019). A total of three points in Figure 4A are observed before the breaking point (indicated by the elbow-shaped before flat points). In the first and second principal components, there is no dominant character to distinguish the examined species, indicated by the value of each principal component $(\leq 16.1 \%$ in the first principal component and $\leq 30.0 \%$ in the second principal component) (Table 1). In the third principal component, only one character with a value $>50 \%$, i.e. shape of sterile laminae $(56.6 \%)$. This character is different within the species examined, i.e. circular-oblong ( $P$. piloselloides), lanceolate $(P$. lanceolata), linear-lanceolate $(P$. angustata), and ellipsoidal to almost ovate ( $P$. nipoboloides).

Figure 4B shows the PCA biplot in this study. According to Donoso-Nanculea (2015), biplot presents both principal component scores of samples and the loading of variables in a single plot. The score of the principal component will group together all the taxa with high similarity. The loading plot indicates how strongly each examined character influences a principal component (David and Jacobs 2014). In Figure 4B, the position of $P$. niphoboloides and $P$. piloselloides is closer and located in the same quadrant, indicating the high similarity of the observed characters. The main characteristic of $P$. nipholoides is the tip of laminae with slightly lobed (C23), while the characteristic of $P$. piloselloides is the base of sterile laminea (C8) and shape of fertile laminea (C21). $P$. angustata and $P$. lanceolata are located in different quadrants. The characteristics of $P$. angustata that are distinguished from the other three species are the weak dimorphic frond (C2) and greyish green color of sterile laminae (C12). P. lanceolata is distinguished from other species based on the acuminate base of sterile laminea (C8) and linear-shaped fertile laminae with below widest (C21). The two characters form a small angle $\left(<90^{\circ}\right)$, indicating a positive correlation. The PCA result shows the main characteristic of each examined species.

In conclusion, Pyrrosia members in this study are characterized by having creeping rhizomes, dimorphic fronds, simple leaves with leathery or fleshy laminae. All species show stellate trichomes with reniform, hipostomatic, pericytic stomata on epidermal cells. Morphologically, the four examined Pyrrosia species can be distinguished based on the shape of laminae, as well as, sori characteristics. This study gives an important contribution to the morphological characteristic of four Pyrrosia species collected from Rumbai Forest, Riau Province. The anatomical approach as well as PCA presented in this study is firstly recorded from Pyrrosia species from Indonesia.

\section{ACKNOWLEDGEMENTS}

The author acknowledges Directorate General of Higher Education and Ministry of Research \& Technology, Indonesia for providing Basic Research Grant led by main author.

\section{REFERENCES}

Cheng D, Zhang Y, Xina X, Gaoa D. 2014 Comparative pharmacognosy of Pyrrosia petiolosa and Pyrrosia davidii. Rev Bras Farmacogn 24: 368-380. DOI: 10.1016/j.bjp.2014.07.017.

Churchill H, Tryon H, Barrington D. 2011. Development of the sorus in tree ferns: Dicksoniaceae. Can J Bot 76 (7): 1245-1252. DOI: $10.1139 /$ B98-122.

Crang R, Sobaski SL, Wise R. 2019. Plant Anatomy-A Concept-Based Approach to The Structure of Seed Plant. Springer. DOI: 10.1007/978-3-319-77315-5.

David C, Jacobs D. 2014. Principal component analysis: a method for determining the essential dynamics of proteins. Humana Press, Totowa, NJ. DOI: 10.1007/978-1-62703-658-0_11.

Dematteis B. Solís S, Yesilyurt J, Meza T, Torres E. 2019. Comparative anatomy in four Cheilanthoid ferns. Bol Soc Argent Bot 54 (2): 203214. DOI: 10.31055/1851.2372.v54.n2.24365.

Dong, X, Wang H, Gu J, Yan W, Wang Z. 2015. Root morphology, histology and chemistry of nine fern species (pteridophyta) in a temperate forest. Plant Soil 393 (1): 1-12. DOI: 10.1007/S11104-0152484-7.

Donoso-Nanculao G, Paredes M, Beccera V, Arrepol C, Balzarini M. 2015. GGE biplot analysis of multi-environment yield trials of rice produced in a temperate climate. Chilean J Agric 76 (2): 152-157. DOI: $10.4067 / \mathrm{S} 0718-58392016000200003$.

Haq F. 2017. Morpho-anatomical description of Lygodium hazaricum Haq. a new contribution to the fern flora of Pakistan. Trop Plant Res 4 (2): 358-362, 2017 DOI: 10.22271/tpr.2017.v4.i2.047.

Hovenkamp P. 1986. A Monograph of The Fern Genus Pyrrosia (Polypodiaceae) by E. J. Brill. Leiden University Press Leiden. 
Jolliffe IT, Cadima J. 2016. Principal component analysis: a review and recent developments. Philos Trans Roy Soc Math Phys Eng Sci 374 (3065). DOI: 10.1098/rsta.2015.0202.

Kato M, Tsutsumi C. 2008. Generic classification of Davalliaceae. Acta Phytotaxonomica Geobotanica 59: 1-14. DOI 10.18942/apg.KJ00004899882.

Koniyo Y, Lumenta C, Olii AH, Mantiri R. 2019. The characteristic and nutrients concentrated leaves of vegetable fern (Diplazium esculentum (Retz.) Swartz) live in different locations. J Phys: Conf Ser 1387 (1) DOI: 10.1088/1742-6596/1387/1/012003.

Kotrnon K, Thammathaworn A, Chantaranothai P. 2007. Comparative anatomy of the genus Pyrrosia Mirbel (Polypodiaceae) in Thailand. Nat History J Chulalongkorn Univ 7 (1): 75-85.

Lagoria M, Avila G, Neira D, Rodríguez A, Norma R, Prado J, Hernández M. 2018. Morphoanatomical and histochemical characteristics of the epiphytic fern Pleopeltis macrocarpa (Polypodiaceae). Braz J Bot 41 (3): 739-750. DOI: 10.1007/s40415-018-0474-8.

Lin YX, Viane R. 2013. Aspleniaceae. In: Wu Z-Y, Raven PH, Hong DY. (eds) Flora Of China, Vol. 2-3. Science Press, Beijing \& Missouri Botanical Garden Press, St. Louis.

Mishra A, Sarkar U, Taraphder S, Datta S, Swain D, Saikhom R, Panda S, Laishram, M. 2017. Multivariate statistical data analysis-principal component analysis (PCA). Intl J Livestock Res 7 (5): 60-78. DOI: 10.5455/ijlr.20170415115235.

Moran R, Paulo L. 2015. Phylogeny of the polybotryoid fern clade (Dryopteridaceae). Intl J Plant Sci 176 (9): 880-891. DOI: $10.1086 / 683393$.

Nagalingum N, Knerr N, Laffan SW. 2015. Continental scale patterns and predictors of fern richness and phylogenetic diversity. Front Genet 6 (132): 1-14. DOI: 10.3389/Fgene.2015.00132.

Nayar BK, Chandra S. 2011. Morphological series within the genus Pyrrosia, and their phylogenetic interpretation. Can J Bot 45 (5): 615 634. DOI: $10.1139 / \mathrm{b} 67-068$.

Nopun PT, Thaweesakdi B, Jenjittikul T. 2016. Systematic importance of rhizome stelar anatomy in selected Monilophytes from Thailand Possathorn. Taiwania 61 (3): 175-184. DOI: 10.6165/tai.2016.61.175 175.

Paul V, Sharma L, Pandey R, Meena RC. 2017. Measurements of stomatal density and stomatal index on leaf/plant surfaces. Manual of ICAR Sponsored Training Programme on "Physiological Techniques to Analyze the Impact of Climate Change on Crop Plants". 16-25 January 2017, Division of Plant Physiology, IARI, New Delhi.

Rakotondrainibe F, Hovenkamp PH. 2012. A new species of Pyrrosia (Polypodiaceae) from Madagascar. Novon J Bot Nomenclature 22 (1): 75-77. DOI: $10.3417 / 2010036$.

Ranil RHG Ranil, Pushpakumara DKNG, Janssen T, Fraser-Jenkins CR, Wijesundara DSA. 2011. Conservation priorities for tree ferns (Cyatheaceae) in Sri Lanka. Taiwania 56 (3): 201-209.

Resmi S, Thomas V, Sreenivas VK. 2016. Stipe anatomical studies on selected pteridophytes of South India. Acta Bot Hung 58 (1-2): 167176. DOI: 10.1556/034.58.2016.1-2.7.

Santos RO, Gorgulho BM, Castro MA, Fisberg RA. Marchioni DA, Baltar FT. 2019. Principal component analysis and factor analysis: differences and similarities in nutritional epidemiology application. Rev Bras Epidemiol 22: 1-14. DOI: 10.1590/1980-549720190041.

Sofiyanti N, Iriani D, Fitmawati, Marpaung AA. 2019a. Morphology, palynology, and stipe anatomy of four common ferns from Pekanbaru, Riau Province, Indonesia. Biodiversitas 20 (1): 327-336. DOI: 10.13057/Biodiv/D200138.

Sofiyanti N, Iriani D, Fitmawati, Roza AA. 2015. Stenochlaena riauensis (Blechnaceae), A new fern species from Riau, Indonesia. Bangladesh J Plant Taxon 22 (2): 137-14. DOI: 10.3329/bjpt.v22i2.26075.

Sofiyanti N, Iriani D, Ftmawati. 2019b. The first record of grass-like fern, Schizaea dichotoma (L.) J. Sm. (Schizaeaceae) From Lingga Island, Indonesia: Its morphological, anatomical and palynological study. Biodiversitas 20 (9): 2651-2660. DOI: 10.13057/Biodiv/D200930.

Sofiyanti N, Isda, MN. 2018. Kajian morfologi dan mikromorfologi (sisik serta trikoma) 4 Jenis Pyrrosia Mirb. (Polypodiaceae) di Provinsi Riau. Jurnal Biologi Tropis 18 (2): 174-181. DOI: 10.29303/jbt.v18i2.857. [Indonesian]

Steševic D, Berg C. 2015. Botrychium matricariifolium, a new fern species for the flora of Montenegro. Acta Bot Croat 74 (1): 181-186. DOI: 10.1515/Botcro-2015-0014.

Taha RM, Haron NW, Wafa SN. 2011. Morphological and tissue culture studies of Platycerium coronarium, a rare ornamental fern species from Malaysia. Am Fern J 101 (4): 241-251. DOI: 10.1640/00028444-101.4.241.

Talip N, Ruzi A, Nadiah N, Nisa RN, Haja K, Solihani SN. 2012. Stipe anatomical characteristics in some Davallia (Davalliaceae) species in Malaysia. Sains Malaysiana 41 (1): 53-62.

Tian N, Wang Y, Zhang W, Jiang Z. 2014. A new structurally preserved fern rhizome of Osmundaceae (Filicales) Ashicaulis wangii sp. Nov. from the jurassic of western Liaoning and its significances for palaeobiogeography and evolution. Sci China Earth Sci 57 (4): 671681. DOI: $10.1007 / \mathrm{S} 11430-013-4767-2$

Tsutsumi C, Praptosuwiryo TN, Kato M. 2018. A preliminary study on mild hemiparasitic epiphytic fern Pyrrosia piloselloides (Polypodiaceae). Bull Nat Mus Nat Sci Ser B 44 (3): 121-125.

Vasco A, Moran Rc, Ambrose Ba. 2013. The evolution, morphology, and development of fern leaves. Front Plant Sci 4 (345): 1-16. DOI: $10.3389 / \mathrm{Fpls} .2013 .00345$.

Vasques DT, Ebihara A, Motomi I. 2017. The felt fern genus Pyrrosia mirbel (polypodiaceae): a new subgeneric classification with a molecular phylogenetic analysis based on three plastid markers. Acta Phytotaxon Geobot 68 (2): 65-82. DOI: 10.18942/Apg.201620.

Watkins J, Churchill A, Holbrook N. 2016. A site for sori: ecophysiology of fertile-sterile leaf dimorphy in ferns. Am J Bot 103 (5): 1-11. DOI: 10.3732/ajb.1500505.

Xu K, Chen C, Kamau P, Liao W, Zhang L. 2019. Four new species of the fern genus Hymenasplenium (Aspleniaceae) from Africa and Asia. Phytotaxa 416 (1): 34-42. DOI: 10.11646/phytotaxa.416.1.4.

Zhang XC, Lu SG, Lin YX, Qi XP, Moore S, Xing FW, Wang FG, Hovenkamp PH, Gilbert MG, Nooteboom HP, Parris BS, Haufler S, Kato M, Smith AR. 2013. Polypodiaceae. In: Wu ZY, Raven PH, Hong DH (eds) Flora of China 2-3 (Pteridophytes). Science Press St. Louis, Missouri Botanical Garden Press, Beijing. 